\title{
Differential predation on marine invertebrate larvae by two benthic predators
}

\author{
Cynthia Cowden ${ }^{1}$, Craig M. Young ${ }^{2 *}$ and F. S. Chia ${ }^{2}$ \\ ${ }^{1}$ Department of Biology, University of the South, Sewanee, Tenessee 37375, USA \\ ${ }^{2}$ Department of Zoology, University of Alberta, Edmonton, Alberta T6G 2E9, Canada
}

\begin{abstract}
Planktotrophic larvae of polychaetes, echinoids, asteroids, gastropods and cirripeds were preyed upon differentially in the laboratory by 2 filter-feeding benthic predators, the ascidian Styela gibbsii and the mussel Mytilus edulis. Differences in predation rate are attributed in part to larval defense mechanisms. Presumed structural defenses (veliger shell, naupliar spines, trochophore setae) were ineffective against the predators investigated. Echinoderm larvae, which had no apparent structural defenses, had the highest survival. S. gibbsii displayed a higher frequency of siphon closure when exposed to echinopluteus larva homogenate than in seawater controls. This is considered preliminary evidence for chemical defense mechanisms possessed by these larvae.
\end{abstract}

\section{INTRODUCTION}

Predation may be one of the major sources of mortality for planktonic larvae of benthic marine invertebrates (Nelson, 1925; Cerruti, 1941; Korringa, 1941, Thorson, 1950). Indeed, Thorson (1950) suggested that the high reproductive potentials exhibited by many marine invertebrates reflect the intensity of predation and other selective pressures operating during the planktonic period. One might predict that a species would respond to intense and predictable predation not only by increasing fecundity, but by evolving adaptations that directly improve larval fitness. Larval spines, setae and shells have often been regarded as defensive adaptations (Wilson, 1929; Foxon, 1934) as have certain behavioral patterns (Singarajah, 1969; Forward, 1977) and chemical substances (Lucas et al., 1979). Although the anecdotal literature on larval defense and predation is substantial (reviewed by Young and Chia, in press), the effectiveness of presumed larval defenses against different predators has seldom been assessed experimentally.

This study examines differential predation on larvae in the laboratory by offering larvae to 2 benthic predators: the mussel Mytilus edulis and the ascidian Styela gibbsii. Larvae were selected from 4 major

- Present address: Department of Biological Sciences, Florida State University, Tallahassee, Florida 32306, USA phyla and included species having several potential defense mechanisms including erectable setae, external shells, spiny exoskeletons and possibly distasteful chemicals (Table 1).

Mytilus edulis has been implicated as an important larval predator (Thorson, 1950), and related species are abundant on many exposed rocky shores in temperate regions (Seed, 1969; Paine, 1974). Styela gibbsii occurs at an average density of $417 \mathrm{~m}^{-2}$ in the fouling community at Friday Harbor, Washington (Young, 1982). It is closely related to numerous species which dominate intertidal, subtidal and fouling communities throughout the world (Millar, 1971; Sutherland, 1978).

While both predators are 'suction feeders', using ciliary currents to draw water and food particles through internal feeding structures, they differ in their mechanisms for selecting or rejecting particles. Mytilus edulis is virtually non-selective in the particles it takes into the mantle cavity. Items of unsuitable size, shape or specific gravity are rejected internally by means of ciliary tracts on the gill lamellae and labial palps (Jørgensen, 1966). Invertebrate larvae may sometimes emerge alive from the pseudofeces but most often die soon after expulsion because of entanglement in mucus (Mileikovsky, 1974). Styela gibbsii, like most other solitary ascidians, selects food according to size and chemical criteria. The rejection mechanism is known as the 'crossed reflex' (Hecht, 1918). Unsuitable particles striking the oral tentacles elicit a response in 
which the excurrent siphon closes, the animal stops filtering, and the body wall muscles contract strongly, expelling water from the incurrent siphon. Larvae and other small animals which are not accepted as food are generally expelled intact and unharmed before entering the branchial sac.

\section{MATERIALS AND METHODS}

Larvae of all 8 species (Table 1) were reared in the laboratory during June, 1981. Spawning was induced in polychaetes by removing them from their tubes, and in echinoids by injection with $0.5 \mathrm{M} \mathrm{KCl}$. Limpets spawned spontaneously shortly after being collected from the field. Egg masses were removed from barnacles by dissection. Gonads were dissected from asteroids and exposed to 1-methyl-adenine prior to artificial fertilization (Stevens, 1970).

The predators Mytilus edulis and Styela gibbsii were collected from the floating breakwater at Friday Harbor Laboratories. $M$. edulis ranged in length from 3.21 to $4.11 \mathrm{~cm}(\overline{\mathrm{x}}=3.67 \mathrm{~cm}, \mathrm{n}=16)$, in height from 1.73 to $2.41 \mathrm{~cm}(\overline{\mathrm{x}}=2.12 \mathrm{~cm}, \mathrm{n}=16)$, and in maximum width from 1.15 to $1.67 \mathrm{~cm}(\overline{\mathrm{x}}=1.37 \mathrm{~cm}, \mathrm{n}=16)$. S. gibbsii ranged in length from 2.51 to $3.79 \mathrm{~cm}(\bar{x}=3.07 \mathrm{~cm}$, $\mathrm{n}=17)$, and in diameter from 0.9 to $1.47 \mathrm{~cm}$ $(\overline{\mathrm{x}}=1.19 \mathrm{~cm}, \mathrm{n}=17)$ with a siphon diameter of approximately $0.5 \mathrm{~cm}$. Both species were cleaned with a small brush and allowed to recover for at least $24 \mathrm{~h}$ before they were used in experiments. They were starved in filtered seawater for $1.25 \mathrm{~h}$ (S. gibbsii) or $2.0 \mathrm{~h} \mathrm{(M}$. edulis) immediately prior to the predation experiments.

The same protocol was followed for all larval types offered to one predator. One hundred larvae were pipetted into each of 13 small culture dishes containing $125 \mathrm{ml}$ of filtered seawater. Either Mytilus edulis or Styela gibbsii were added to 10 of the dishes (1 individual dish ${ }^{-1}$ ); 3 dishes were maintained as predatorfree controls. The experiments were terminated by removing the predators after $1.5 \mathrm{~h}$ for $M$. edulis and after $3.0 \mathrm{~h}$ for $S$ gibbsii.

Surviving larvae were counted in a Bogorov Tray under a dissecting microscope after removing twothirds of the seawater by suction through a $70 \mu \mathrm{m}$ Nitex screen. Loss of larvae in control dishes measured the handling error for each prey species. The observed number of survivors in the experimental dishes was multiplied by a correction constant calculated to increase the mean number of survivors in the 3 control dishes to 100 . These transformed data were used in the Kruskal-Wallis Test to eliminate as much handling error as possible from the observed survival rates. Dunn's nonparametric a posteriori test (Hollander and
Wolf, 1973) was used to make pairwise comparisons between species.

In a separate experiment, veligers of the nudibranch Archidoris montereyensis were offered to predators. Pseudofeces, feces and guts were examined for larval shells in order to verify the fate of the larvae.

To test the hypothesis that defensive chemicals possessed by echinoderm larvae reduce predation by Styela gibbsii, we compared rejection behavior of the ascidians in the presence and absence of homogenized larvae. Pluteus larvae of Dendraster excentricus or Strongylocentrotus purpuratus ( $0.6 \mathrm{~g}$ wet weight) were macerated in a manually operated tissue homogenizer with $4 \mathrm{ml}$ of filtered seawater and used immediately. Matched pairs of $S$ gibbsii were placed in separate dishes containing $60 \mathrm{ml}$ of seawater. Two $\mathrm{ml}$ of homogenate were added to one of the dishes. The ascidians were then watched continuously for $45 \mathrm{~min}$. When either ascidian closed its siphons, a + was recorded for that individual. The other individual was also scored as a + if its siphons were closed at the same instant, or as a 0 if its siphons were open. The sum of + scores after the experiment was taken as a measure of frequency and duration of closure and termed the 'siphon closure score'. Six replicate experiments were performed with homogenates of each of the 2 larval types.

\section{RESULTS}

The larvae offered to predators ranged in maximum linear dimension from approximately $100 \mu \mathrm{m}$ to $350 \mu \mathrm{m}$ at the time of the experiments (Table 1).

Survival rates among the 6 larval types offered to Mytilus edulis differed significantly overall (KruskalWallis Test; $\mathrm{H}=19.01, \mathrm{p}=0.002$ ). The 3 echinoderm species had the highest survival rates, though these did not differ significantly from that of Serpula vermicularis (Fig. 1). Intact larvae of Pisaster ochraceous were observed in the pseudofeces. However, they were securely entangled in inucus and not counted as survivors. Survival of Pollicipes polymerus and Sabellaria cementarium was significantly lower than that of Strongylocentrotus franciscanus.

Larvae of several species showed much higher survival rates in the presence in Styela gibbsii than in the presence of Mytilus edulis. Moreover, S. gibbsii discriminated among more larval types than did $M$. edulis (Fig. 1). The overall difference in $S$. gibbsii experiments was highly significant (Kruskal-Wallis Test; $\mathrm{H}=42.39, \mathrm{p}=0.001$ ). An a posteriori comparison revealed that Dendraster excentricus survived better than any of the 4 non-echinoderms tested and that Pisaster ochraceous survived better than either of the 
Table 1. Age, size and potential defense mechanisms of 8 larval types offered to Mytilus edulis and Styela gibbsii

\begin{tabular}{|c|c|c|c|}
\hline $\begin{array}{l}\text { Group, larval form and } \\
\text { species }\end{array}$ & $\begin{array}{c}\text { Age (d) } \\
\text { post-fertilization }\end{array}$ & $\begin{array}{r}\text { Greatest linear } \\
\text { dimension }(\mu \mathrm{m})\end{array}$ & $\begin{array}{l}\text { Potential defense } \\
\text { mechanism }\end{array}$ \\
\hline \multicolumn{4}{|l|}{ Polychaeta: trochophore } \\
\hline Serpula vermicularis & 3 & 100 & Unknown \\
\hline Sabellaria cementarium & 6 & 250 & Setae, behavior \\
\hline \multicolumn{4}{|l|}{ Echinoidea: echinopluteus } \\
\hline Strongylocentrotus purpuratus & 3 & 200 & Skeletal rods, chemicals \\
\hline Strongylocentrotus franciscanus & 6 & 200 & Skeletal rods, chemicals \\
\hline Dendraster excentricus & 7 & 200 & Skeletal rods, chemicals \\
\hline \multicolumn{4}{|l|}{ Asteroidea: bipinnaria } \\
\hline Pisaster ochraceous & 5 & 350 & Chemicals \\
\hline \multicolumn{4}{|l|}{ Gastropoda: veliger } \\
\hline Notoacmaea scutum & 2 & 250 & Larval shell \\
\hline \multicolumn{4}{|l|}{ Crustacea: nauplius } \\
\hline Pollicipes polymerus & $\begin{array}{c}2 \\
\text { (post-hatching) }\end{array}$ & 300 & Exoskeleton, spines \\
\hline
\end{tabular}

polychaete species. Strongylocentrotus purpuratus, which is closely related to $D$. excentricus, did not differ significantly from either the non-echinoderm or echinoderm species.

Veliger larvae of Archidoris montereyensis have conspicuous larval shells which are easily recovered in the guts and feces of filter-feeders. A large number of

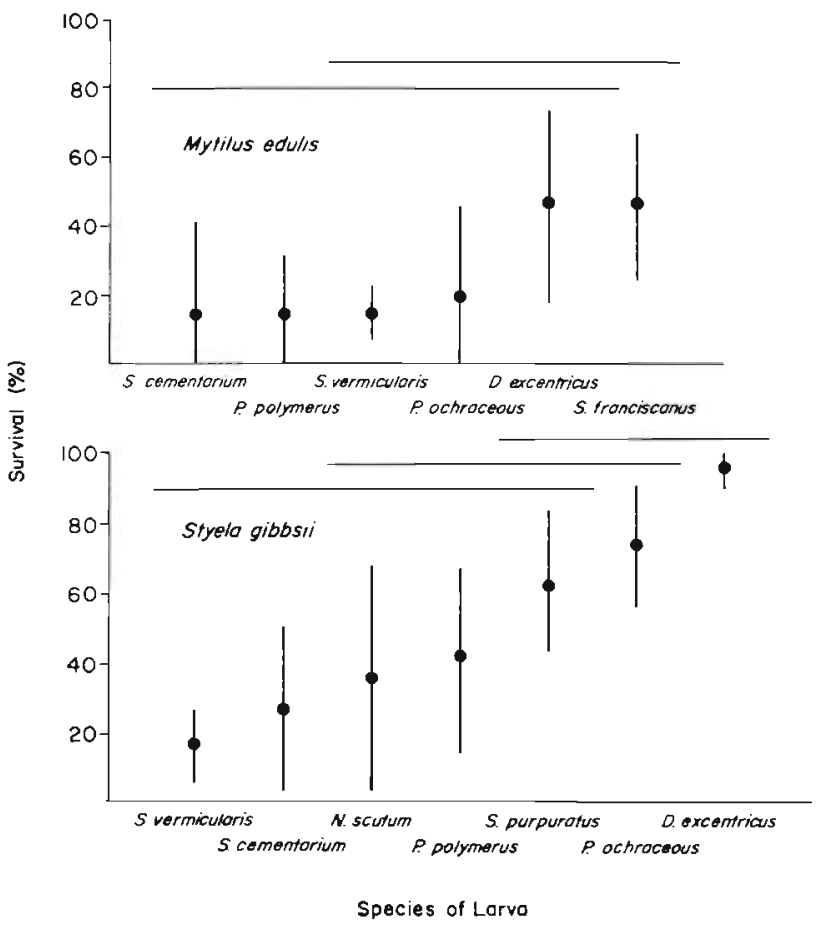

Fig. 1. Survival rates of 8 larval types offered to Mytilus edulis (top) and Styela gibbsii (bottom). Symbols represent mean \pm 1 S.D. of 10 replicates, each consisting of 100 larvae with 1 predator. Horizontal bars group non-significant differences $(p<0.05)$ as determined by Dunn's a posteriori test veligers were maintained in beakers with the 2 predators. After $2 \mathrm{~h}$, guts of Mytilus edulis (removed by dissection) contained veliger protoconchs. Twentyfour $h$ after the experiments were initiated, shells were also found in the feces of Styela gibbsii, confirming that larvae had indeed been ingested and not lost in some other way.

Styela gibbsii, had significantly higher siphon closure scores when exposed to extracts of Dendraster excentricus or Strongylocentrotus purpuratus larvae than in filtered seawater (Fig. 2; Randomization Test, $\mathrm{p}=0.016$ and $\mathrm{p}=0.031$ )

\section{DISCUSSION}

Under the conditions of this laboratory study, larvae selected from 4 major phyla and differing in form, behavior and chemical composition were not equally susceptible to predation by two benthic filter-feeders. Because of the small size of invertebrate larvae, it is difficult to demonstrate experimentally the precise nature of the traits that reduce predation. In some adult invertebrates, the defensive value of external structures has been documented by noting any increase in predation rate following their experimental removal (Nance and Braithwaite, 1979; Young, 1982). In both adults and larvae, defensive chemicals have been isolated and used to render normally palatable foods unacceptable to predators (Lucas et al., 1979; Stoecker, 1980).

A potential problem with studying larval predation in a container of still seawater is that the predator-prey encounters may be influenced by geometry and size of the container, the pumping rate of the predator and the 


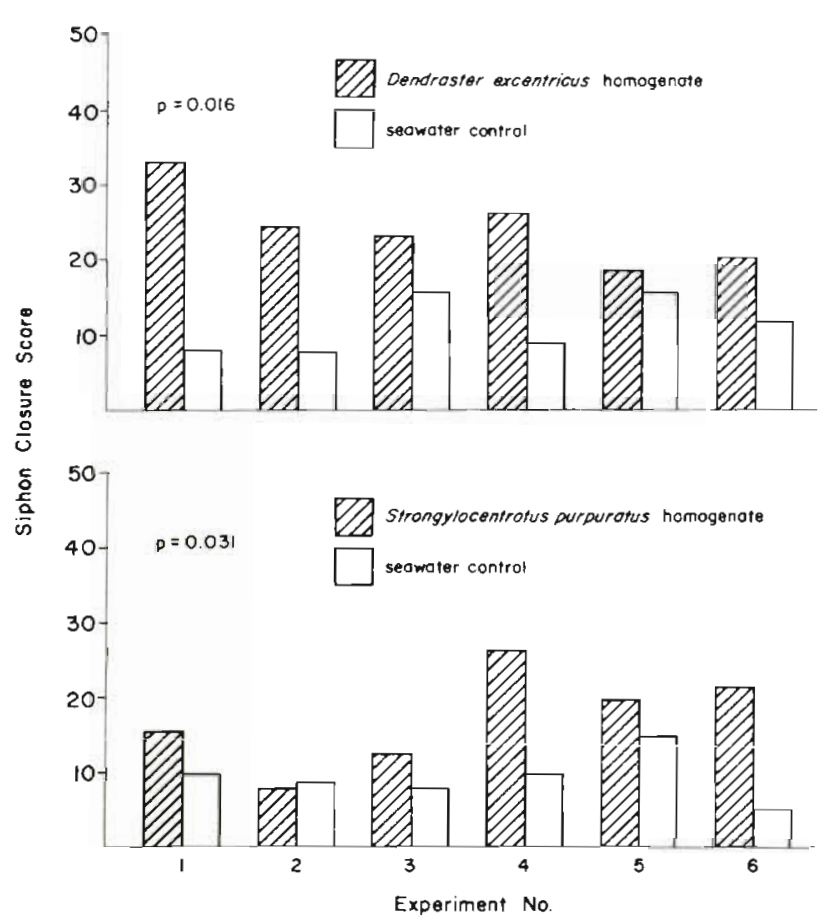

Fig. 2. Styela gibbsii. Number of siphon closure observations recorded during 6 separate $45 \mathrm{~min}$ experiments in which ascidians were exposed to echinoderm larva homogenate or to seawater only (control)

behavior of the larvae themselves. Even non-defensive behavior may affect the encounter rate. For example, geo-negative larvae might remain near the surface throughout the experiment, encountering feeding currents of the predator less frequently than would a larva swimming randomly. Water volume in our experiments was limited to $125 \mathrm{ml}$ in order to minimize this source of error. Both predator species seemed capable of completely mixing this small volume when actively feeding.

All of the predicted structural defense mechanisms were completely ineffective against Styela gibbsii and Mytilus edulis. Particularly surprising was very low survivorship of trochophores of Sabellaria cementarium. These larvae possess numerous long, barbed setae which trail behind while swimming. When disturbed, the larvae stop swimming and extend their setae to the sides, surrounding themselves with spines and greatly increasing their effective size. Despite this behavior, the sabellarid larvae survived no better than unarmed trochophores of Serpula vermicularis. The spined nauplii of the goose barnacle Pollicipes polymerus and the shelled veligers of the limpet Notoacmaea scutum also showed low survival. The ineffectiveness of these structural defenses against benthic predators investigated in this study does not preclude their possible defensive function against planktonic predators (e.g. polychaete larvae, medusae, cteno- phores, chaetognaths, larval fishes) or against other benthic predators. Also, it is unlikely that those larvae experiencing minimal predation in our experiments will be defended effectively against all potential predators.

In experiments with both mussels and ascidians, larvae of 4 echinoderms ( 3 echinoids and 1 asteroid) survived better than larvae of other species, and the differences among echinoderms were all non-significant. High survival of echinoderm larvae could be explained by any of 3 hypotheses which are not mutually exclusive: rejection based on size, low encounter rate due to behavior, or rejection based on chemical composition. Bipinnariae of Pisaster ochraceous were the longest of any larvae tested. However, they were comparable in width to those of most of the other species. All of the echinoplutei, despite their long arms, were smaller than larvae of Notoacmaea scutum, Pollicipes polymerus and Sabellaria cementarium (setae extended). Thus, size probably does not enhance survival of echinoderm larvae. Observations of larvae in culture suggest that the echinoderms swim as randomly as any of the other species. If swimming behavior reduced predation, it would probably be manifested more strongly in species such as Serpula vermicularis and Pollicipes polymerus which demonstrate strong photoresponses.

We consider chemical defense as the most likely explanation for high survivorship of echinoderm larvae. Saponin compounds occur in starfish larvae, where they reduce predation by planktivorous fishes (Yamaguchi, 1975; Lucas et al., 1979). Although saponins have not been reported in echinoid larvae or embryos, they are known to occur in adult sea urchins (Mackie et al., 1977). Herouard (1911) noted that scyphistomae of the scyphomedusa Chrysaora hysoscella would feed readily on pieces of ovary from Strongylocentrotus sp. but would not accept spawned eggs from the same species.

Further evidence for chemical defense of echinoderm larvae comes from larval homogenate experiments. Styela gibbsii demonstrated 'rejection behavior' more frequently in low concentrations of echinoderm larval homogenate than in plain seawater controls. These ascidians probably were not rejecting particles on the basis of size, since macerated larvae were much smaller than food particles normally taken into the branchial basket.

Despite the fact that experiments with Styela gibbsii were run for twice as long as experiments with Mytilus edulis, mortality in the latter experiments was higher for nearly all species, and more significant differences among species were seen in the former. These differences probably reflect the different nature of the food rejection mechanisms in the 2 predators. Larvae taken 
into the mantle cavity of $M$. edulis, even if unacceptable as food, are likely to be dead by the time they are expelled in the pseudofeces (Mileikovsky, 1974), whereas larvae rejected by ascidians generally emerge unharmed. We infer from these observations that while both ascidians and mussels may be encountered by larvae swimming in shallow marine habitats, the larvae are more likely to recruit into a dense stand of ascidians than into a mussel bed. Although numerous organisms occupy the interstices of a mat of $M$. edulis, diversity is often low, and many of the organisms are motile ones with the potential of migrating in after settlement (Ricketts and Calvin, 1968). Even larvae of $M$. edulis which are cannibalized by the adults (Thorson, 1950) do not settle directly in the beds, but attach to filamentous substrata on the nearby shore (Block and Geelen, 1958; Bayne, 1965) then move into the beds after some growth (Bayne, 1964; Seed, 1969). $M$. californianus also recruits in this way (Paine, 1974).

The major point of the present work is that predation on larvae by some benthic filter-feeders is differential, not indiscriminate. If such differential predation occurs in the field, it could have important consequences in hard-bottom communities as well as in dense assemblages of infaunal invertebrates (Woodin, 1976). Larvae defending themselves effectively against benthic predators will have a numerical advantage in surviving sources of post-settling mortality and may also occupy habitats unavailable to species whose larvae are readily consumed.

Acknowledgements. We wish to thank Dr. A. O. D. Willows for providing research facilities at Friday Harbor Laboratories, University of Washington. This research was supported by a Natural Sciences and Engineering Research Council of Canada grant to F. S. Chia.

\section{LITERATURE CITED}

Bayne, B. L. (1964). Primary and secondary settlement in Mytilus edulis (Mollusca). J. Anim. Ecol. 33: 513-523

Bayne, B. L. (1965). Growth and delay of metamorphosis of the larvae of Mytilus edulis (L). Ophelia 2: 1-47

Block, J. W. de, Geelen, H. J. (1958). The substratum required for the settling of mussels (Mytilus edulis). Archs. néerl. Zool. 13 (Suppl. 1): 446-460

Cerruti, A. (1941). Osservazioni ed esperimenti sulle cause di distrizione deele larve d'ostrica nel Mar Piccolo e nel Mar Grande di Taranto. Archo Oceanogr. Limnol. 1: 165-201

Forward, R, B., Jr. (1977). Occurrence of a shadow response among brachyuran larvae. Mar. Biol. 39: 331-341

Foxon, G. E. H. (1934). Notes on the swimming methods and habits of certain crustacean larvae. J. mar. biol. Ass. U.K. 19: $829-849$

Hecht, S. (1918). The water current produced by Ascidia atra Lesueur. J. exp. Zool. 20: 429-434

Herouard, E. (1911). Le pharynx des scyphistomes. Zool. Anz. 38: $231-233$
Hollander, M., Wolf, D. (1973). Nonparametric statistical methods. Wiley and Sons, Niw York

Jørgensen, C. B. (1966). Biology of suspension feeding. Pergamon, New York

Korringa, P. (1941). Experiments and observations on swarming, pelagic life and settling in the European flat oyster, Ostrea edulis L. Archs néerl. Zool. 5: 1-249

Lucas, J. S., Hart, R. J., Howen, M. E., Salathe, R. (1979). Saponins in eggs and larvae of Acanthaster planci (Asteroidea) as a chemical defense against planktivorous fish. J. exp. mar. Biol. Ecol. 40: 155-165

Mackie, A. M., Singh, H. T., Owen, J. M. (1977). Studies on the distribution, biosynthesis and function of saponins in echinoderms. Comp. Biochem. Physiol. 56B: 9-14

Mileikovsky, S. A. (1974). On predation of pelagic larvae and early juveniles of marine bottom invertebrates and their passing alive through their predators. Mar. Biol. 26: 303-311

Millar, R. H. (1971). The biology of ascidians. Adv. mar. Biol. 9: $1-100$

Nance, J. M., Braithwaite, L. F. (1979). The function of mucous secretions in the cushion star Pteraster tesselatus Ives. J. exp. mar. Biol. Ecol. 40: 259-266

Nelson, I C. (1925). On the occurrence and food habits of ctenophores in New Jersey inland coastal waters. Biol. Bull. mar. biol. Lab., Woods Hole 48: 92-111

Paine, R. T. (1974). Intertidal community structure-experimental studies on the relationship between a dominant competitor and its principal predator. Oecologia 15: 93-120

Ricketts, E. F., Calvin, J. (1968). Between Pacific tides, 4th ed.; revised by J. W. Hedgepeth. Stanford University Press, Stanford, California

Seed, R. (1969). The ecology of Mytilus edulis L. on exposed rocky shores. I. Breeding and settlement. Oecologia 3: $277-316$

Singarajah, K. V (1969). Escape reactions of zooplankton: the avoidance of a pursuing siphon tube. J. exp. mar. Biol. Ecol. 3: 171-178

Stevens, M. (1970). Procedures for induction of spawning and induction of maturation of starfish oocytes by treatment with 1-methyl-adenine. Expl Cell Res. 59: 482-484

Stoecker, D. (1980). Chemical defenses of ascidians against predators. Ecology 61: 1327-1334

Sutherland, J. P. (1978). Functional roles of Schizoporella and Styela in the fouling community at Beaufort, North Carolina. Ecology 59: 257-264

Thorson, G. (1950). Reproduction and larval ecology of marine bottom invertebrates. Biol. Rev. 25: 1-45

Wilson, D. P. (1929). The larvae of British sabellarians. J. mar. biol. Ass. U.K. 16: 221-269

Woodin, S. A. (1976). Adult-larval interactions in dense infaunal assemblages-patterns of abundance. J. mar. Res. 34: 25-41

Yamaguchi, M. (1975). Coral reef asteroids of Guam. Biotropica $7: 12-23$

Young, C. M. (1982). Larval behavior, predation and early post-settling mortality as determinants of spatial distribution in subtidal solitary ascidians of the San Juan Islands, Washington. Dissertation, University of Alberta

Young, C. M., Chia, F. S. (in press). Abundance and distribution of pelagic larvae as influenced by predatory, behavioral and hydrographic factors. In: Giese, A. C., Pearse, J. S. (ed.) Reproduction of marine invertebrates, Vol. 9. Academic Press, New York and London 